\title{
Florida Cultivation Guide for Malabar Spinach ${ }^{1}$
}

\author{
Yuheng Qiu and Guodong Liu
}

\section{General Description}

Malabar spinach (Basella spp.) is a nutritious vegetable in the family Basellaceae. It is native to tropical South Asia, including the Indian subcontinent and New Guinea. It was probably naturalized in China, tropical Africa, Belize, Brazil, Colombia, Fiji, French Polynesia, and the West Indies (Fisher et al. 2010, Baksh-Comeau et al. 2016). This species can be found in tropical regions of Africa, South America, and Southeast Asia today (Deshmukh and Gaikwad 2014). Malabar spinach goes by many names, including Indian spinach, Ceylon spinach, vine spinach, and climbing spinach. In Mandarin Chinese, Malabar spinach is called "Muercai" or "Luokui" (Deshmukh and Gaikwad 2014, Singh et al. 2018). Malabar spinach has long been established in cultivation in China and India. This spinach is a potential cash crop to Florida, being grown currently only for niche markets. However, Florida's suitable climate coupled with Malabar spinach's great taste and nutritional quality suggest that this crop has great potential for commercial production (Parkell et al. 2016, Stephens 2018).

Malabar spinach describes three species that are differentiated by growth habit and leaf shape. Basella alba ("alba" means "white" in Latin) has dark green oval or round leaves (Figure 1); B. rubra ("rubra" means "red" in Latin) has reddish oval-to-round leaves; and B. cordifolia ("cordifolia" means "heartleaf" in Latin), a synonym to B. alba, has dark green cordate leaves (Fern 2014). Basella rubra is typically cultivated as landscape ornamental plants, while $B$. alba and $B$. cordifolia are the species preferred for dietary uses. Demand for Malabar spinach may be driven by its health benefits. These species contain natural antioxidants that are needed by humans. Basella alba is high in phenols and vitamins A and C. Basella rubra is high in alkaloids and tannin contents. Basella cordifolia has the highest content of anthraquinone among all three Basella species (AdeneganAlakinde and Ojo 2019).

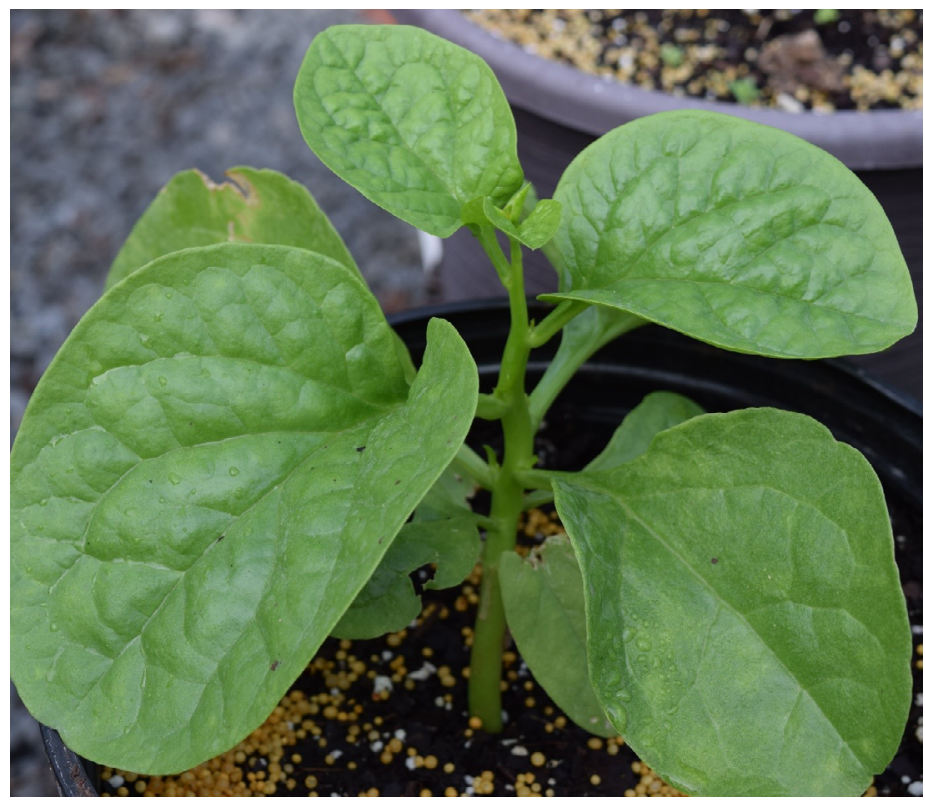

Figure 1. Malabar spinach (Basella alba) dark green oval or round leaves.

Credits: Chunfang Li, FDACS-DPI

\section{Propagation}

The seed of Malabar spinach usually has a rounded shape and brown-black color (Figure 2). Malabar spinach may be seeded $1 / 4$ inch deep in rows spaced 12 to 18 inches

1. This document is HS1371, one of a series of the Horticultural Sciences Department, UF/IFAS Extension. Original publication date September 2020. Visit the EDIS website at https://edis.ifas.ufl.edu for the currently supported version of this publication.

2. Yuheng Qiu, OPS Technical, M.S., and Guodong Liu, associate professor, Horticultural Sciences Department, UF/IFAS Extension, Gainesville, FL 32611.

The Institute of Food and Agricultural Sciences (IFAS) is an Equal Opportunity Institution authorized to provide research, educational information and other services

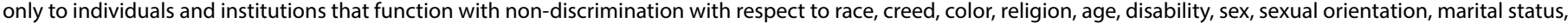

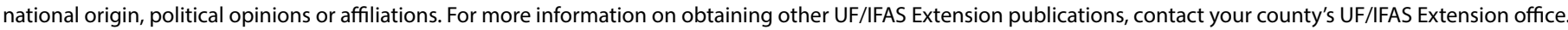
U.S. Department of Agriculture, UF/IFAS Extension Service, University of Florida, IFAS, Florida A \& M University Cooperative Extension Program, and Boards of County Commissioners Cooperating. Nick T. Place, dean for UF/IFAS Extension. 
apart, with 1 to 2 inches between seeds, and thinned to 6 inches between adjacent plants (Ernst 2017). It may take two to three weeks to germinate the seeds at the optimal temperature of $65^{\circ} \mathrm{F}-75^{\circ} \mathrm{F}$ (Cornell 2006). Water soaking is highly recommended to reduce time to germination. For transplanting, simply space the seedlings around 12 inches apart (Cornell 2006).

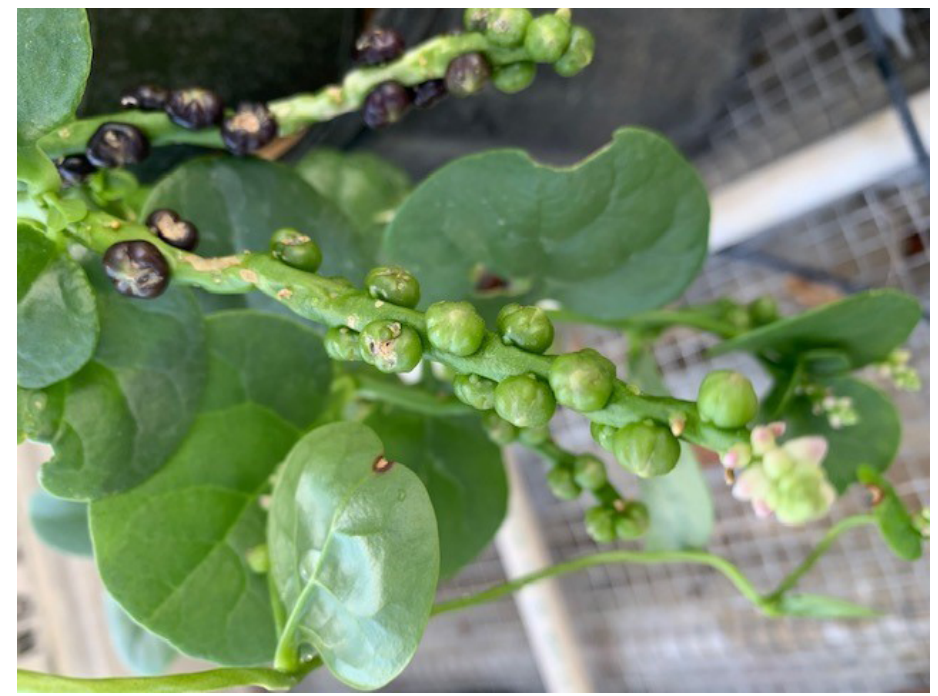

Figure 2. Malabar spinach fruit, with developing seeds, rounded shape, and brown-black color.

Credits: Chunfang Li, FDACS-DPI

Malabar spinach is extremely vulnerable to frost and should not be planted until the soil temperature reaches $65^{\circ} \mathrm{F}-75^{\circ} \mathrm{F}$ to reduce risk of frost damage, usually 2 to 3 weeks after last frost date (Cornell 2006). This spinach type grows as a perennial in USDA Plant Hardiness Zone 10 (south Florida) and can grow during warm seasons in zones as low as Zone 7 (Figure 3). For example, recommended earliest planting dates in north central Florida (Zone 8) would be early summer, around late May or early June.

\section{Growing Conditions}

Malabar spinach grows optimally when the ambient temperature is at least $80^{\circ} \mathrm{F}$ or even exceeding $90^{\circ} \mathrm{F}$. Growth retards when temperature is lower than $80^{\circ} \mathrm{F}$, and it cannot grow when temperatures are consistently lower than $60^{\circ} \mathrm{F}$. Malabar cannot tolerate any frost (Cornell 2006, Fern 2014). While full-sun cultivation does not harm plants, partial shade may be beneficial by facilitating development of larger and more succulent leaves (Cornell 2006, Fern 2014). Because Malabar spinach is a fast-growing vine that can grow six feet or even longer (Parkell et al. 2016), it is typically grown on a trellis or fence to help climbing and to facilitate periodic pruning by cutting off the fleshy leaves and overlong vines to keep desired shape (Cornell 2006, Singh et al. 2018, Stephens 2018).

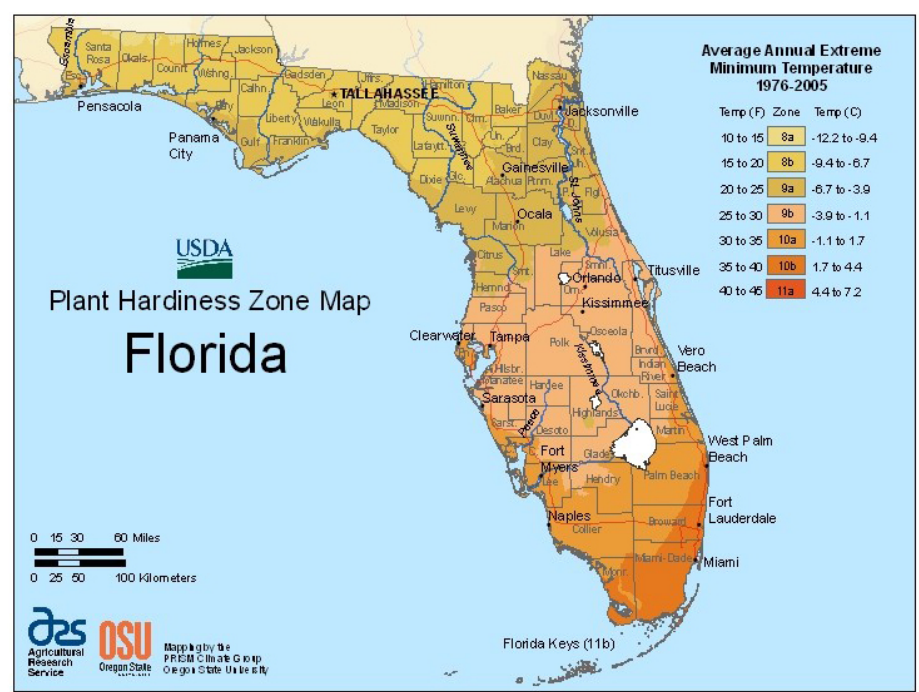

Figure 3. Plant Hardiness Zone Map of Florida (adapted from USDAARS 2012).

Moisture plays a key role in Malabar spinach development, because lack of moisture may lead to a bitter-tasting leaf and blooming (Figure 4). Optimal mean annual rainfall ranges from 80 to 100 inches, but Malabar spinach can tolerate 30 to 160 inches (Fern 2014). Regular irrigation that provides continuous moisture is required for growing Malabar spinach to help maximize quality and prevent blossoming and leaf bitterness (Cornell 2006, Ernst 2017).

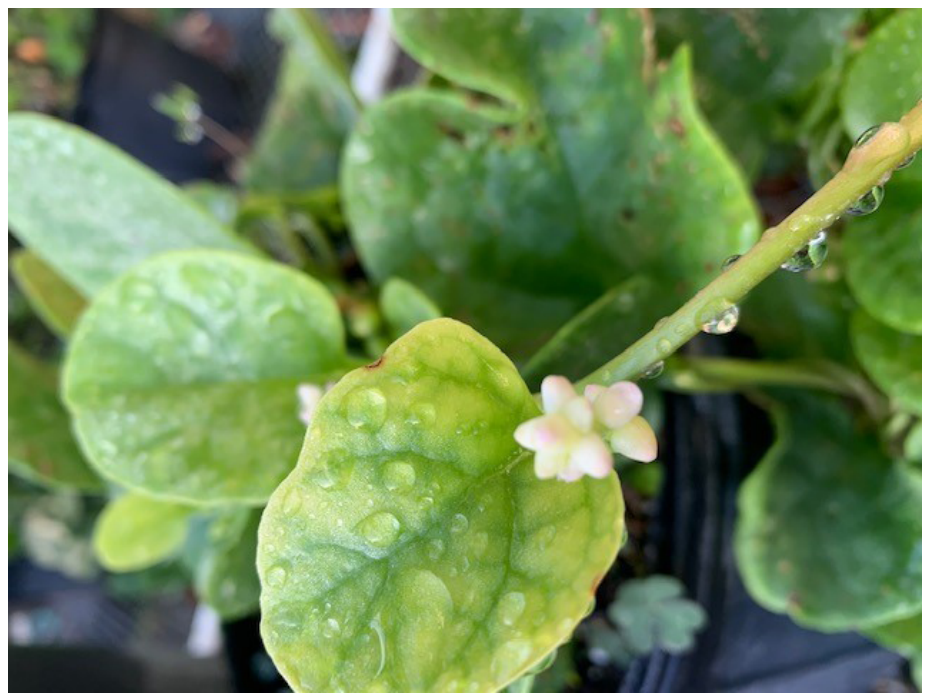

Figure 4. Malabar spinach flower. Credits: Chunfang Li, FDACS-DPI

\section{Soil and Fertilizer}

Malabar spinach grows well in a variety of soils. It grows optimally in sandy loam soils with appropriate moisture and high organic matter content with a $\mathrm{pH}$ of 5.5 to 7.0. Also, it can tolerate soil $\mathrm{pH}$ in the range from 4.3 to 7.5 (Fern 2014). For Malabar spinach plants grown in poor sandy soil, application of $\mathrm{N}$ fertilizer as ammonium nitrate at a rate of $80 \mathrm{lb} / \mathrm{ac}$ with $\mathrm{P}_{2} \mathrm{O}_{5}$ as triple superphosphate 
and $\mathrm{K}_{2} \mathrm{O}$ as sulphate of potash at $18 \mathrm{lb} / \mathrm{ac}$ may produce high-quality leaves and yields. A greater application rate is not recommended due to environmental and economic concerns such as water pollution, nutrient accumulation, and high cost of fertilizer (Rop et al. 2012).

\section{Pests and Diseases}

Malabar spinach is favored by many home gardeners because of its high resistance to many common pests and diseases (Ernst 2017). The presence of flavonoid glycosides in the leaves of Malabar spinach results in resistance to tobacco cutworms (Spodoptera litura) (Aboshi et al. 2018). However, plants may still be susceptible to fungal leaf spots (Cercospora beticola), snails (Achatina fulica), and nematodes (Pratylenchus penetrans) (CABI 2020), which may result in reduced plant growth and leaf quality (Ernst 2017). Frequent monitoring may help determine strategies for pest control, such as removal and destruction of infected leaves to prevent spread (ECHO 2020, Ernst 2017).

\section{Harvest and Storage}

Malabar spinach grows rapidly and reaches maturity around 70 days from seed in optimal conditions. Hand harvest is recommended by trimming the leaves and young stems, the most marketable parts of the plant (Ernst 2017). The optimal storage temperature and time for Malabar spinach is between $50^{\circ} \mathrm{F}-60^{\circ} \mathrm{F}$ and $12-14$ days, respectively (Gimena et al. 2000). Malabar spinach may develop yellow leaves, quality deterioration, and loss of ascorbic acid when storage temperature is high $\left(77^{\circ} \mathrm{F}\right)$. Also, low temperatures $\left(30^{\circ} \mathrm{F}-40^{\circ} \mathrm{F}\right)$ will cause chilling injury and higher $\mathrm{CO}_{2}$ production resulting from ion leakage (Gimena et al. 2000).

\section{Uses}

Malabar spinach is a pseudo-spinach; its leaf superficially resembles spinach, but with a mild lemon-peppery flavor. This vegetable can be eaten either raw in salad mixes or stir-fried with garlic. Malabar spinach is found in many Asian groceries, being an integral component of Southeast Asian and Indian cuisine. Unlike spinach, the mucilaginous quality of Malabar spinach allows it to sustain the heat of soups and stews, making it a popular ingredient in Asian cuisine (Deshmukh and Gaikwad 2014, Fern 2014). Malabar spinach is a nutritious vegetable both raw and cooked, being rich in vitamins (Vitamin A and C), minerals (calcium, magnesium, phosphorus, potassium), and several essential amino acids and antioxidants, including leucine and lysine (Tables 1 and 2) (Deshmukh and Gaikwad 2014, Singh et al. 2018, USDA-ARS 2019a, USDA-ARS 2019b).
Malabar spinach, in particular Basella rubra because of its colorful reddish leaf veins and stems (Deshmukh and Gaikwad 2014), can be incorporated into ornamental landscapes (Fern 2014). Some people have a concern that Basella rubra tends to be invasive if not kept in check, but fortunately it is relatively easy to uproot. To be safe, always remove all plant materials after harvest. The ripe fruit of Malabar spinach is a good source of natural dyes, which could be used either for a titrimetric reaction indicator or for food colorant, because the effective pigment (betacyanin) can maintain enough stability in changing $\mathrm{pH}$, temperature, and light conditions (Deshmukh and Gaikwad 2014, Fern 2014).

Medicinal uses for Malabar spinach have long been reported in tropical South Asia (Deshmukh and Gaikwad 2014, Singh et al. 2018). The cooked roots can help to treat constipation and diarrhea; also, the paste of leaves can treat boils, sores, and wounds (Deshmukh and Gaikwad 2014, Fern 2014, Singh et al. 2018). Methanol extracts of Malabar spinach showed great antimicrobial activity against E. coli and effective antiviral activity that is attributed to the presence of ribosome-inactivating proteins (Bolognesi et al. 1997, Oyewole and Kalejaiye 2012). Also, because of Malabar's richness in phenolic compounds and vitamin C, Malabar extracts exhibited excellent antioxidant activity, which offers protection against free radical mediated damages (Anusuya et al. 2012, Reshmi et al. 2012).

\section{Marketability and Future Outlook}

Because of its high nutritional and medicinal values, Malabar spinach has been widely cultivated in Asia for use as a delicious leafy vegetable. Although spinach is popular in the United States and can be found in every grocery store, Malabar spinach is currently only available in Asian markets (Ernst 2017, Parkell et al. 2016). Malabar spinach could become as popular as traditional spinach because of its pleasant taste, especially for customers willing to try authentic Asian food. Cooking demonstrations and recipes may be introduced to help the community learn more about Asian cuisine and culture (Ernst 2017). Cooking Malabar spinach is extremely easy-stir-fry in a large wok with oil, garlic, and soy sauce. This vegetable can also be fried or stewed with such items as mushrooms, sliced pork, and eggs. According to the University of Kentucky Extension, a small-scale (100-foot row) production of Malabar spinach can generate around $\$ 120$ net profit (Ernst 2017). Malabar spinach has already been cultivated in Hawaii and Puerto Rico (USDA-NRCS 2020). Combined with its adaptability to hot weather, there is a great potential to cultivate Malabar spinach in warm areas in the lower 48 states, particularly in the tropical and subtropical climate of Florida. 


\section{References}

Aboshi, T., S. Ishiguri, Y. Shiono, and T. Murayama. 2018. "Flavonoid glycosides in Malabar spinach Basella alba inhibit the growth of Spodoptera litura larvae." Bioscience, Biotechnology, and Biochemistry 82 (1): 9-14.

Adenegan-Alakinde, T. A., and F. M. Ojo. 2019. "Phytochemical and antioxidant properties of forms of Basella." International Journal of Vegetable Science 25 (5): 431-440.

Anusuya, N., R. Gomathi, S. Manian, V. Sivaram, and A. Menon. 2012. "Evaluation of Basella rubra L., Rumex nepalensis Spreng and Commelina benghalensis L. for antioxidant activity." International Journal of Pharmacy and Pharmaceutical Sciences 4 (3): 714-720.

Baksh-Comeau, Y., S. S. Maharaj, C. D. Adams, S. A. Harris, D. L. Filer, and W. D. Hawthorne. 2016. "An annotated checklist of the vascular plants of Trinidad and Tobago with analysis of vegetation types and botanical 'hotspots.' Phytotaxa 250:1-431.

Bolognesi, A., L. Polito, F. Olivieri, P. Valbonesi, L. Barbieri, M. G. Batteli, M. V. Carusi, E. Benvenuto, F. D. V. Blanco, A. Di Maro, A. Parente, M. Di Loreto, and F. Stirpe. 1997. "New ribosome-inactivating proteins with polynucleotide: Adenosine glycosidase and antiviral activities from Basella rubra L. and Bougainvillea spectabilis Willd." Planta 203 (4): 422-429.

CABI. 2020. "Basella alba (Malabar spinach)." Invasive Species Compendium. Wallingford, UK: CAB International. Accessed May 4, 2020. https://www.cabi.org/isc/ datasheet/8273

Cornell University. 2006. "Explore Cornell: Home gardening flower growing guides." Cornell University Home Gardening. Accessed March 30, 2020. http://www.gardening.cornell.edu/homegardening/scene9529.html

Deshmukh, S. A., and D. K. Gaikwad. 2014. "A review of the taxonomy, ethnobotany, phytochemistry and pharmacology of Basella alba (Basellaceae)." Journal of Applied Pharmaceutical Science 4 (1): 153-165.

ECHO Community. 2020. "Malabar spinach." ECHO Community. Accessed May 4, 2020. https://www.echocommunity.org/en/resources/ c28fd084-e5f5-4d31-9b26-bc11f0388b07

Ernst, M. 2017. Malabar Spinach. CCD-CP-130. Lexington, KY: Center for Crop Diversification, University of Kentucky
College of Agriculture, Food and Environment. Accessed March 30, 2020. https://www.uky.edu/ccd/sites/www.uky. edu.ccd/files/malabar.pdf

Fern, K. 2014. “Basella alba." Tropical Plants Database. Accessed March 30, 2020. http://tropical.theferns.info/ viewtropical.php?id=Basella+alba

Fischer, E., K. Rembold, A. Althof, and J. Obholzer. 2010. "Annotated checklist of the vascular plants of Kakamega forest, Western province, Kenya." Journal of East African Natural History 99:129-226.

Gimena, E. F., K. Kawada, and T. Matsui. 2000. "Effects of storage temperature on the keeping quality of Malabar spinach (Basella alba L.)." Food Preservation Science 26 (4): 211-217.

Oyewole, O. A., and O. A. Kalejaiye. 2012. "The antimicrobial activities of ethanolic extracts of Basella alba on selected microorganisms." Scientific Journal of Microbiology 1 (5): 113-118.

Parkell, N. B., R. C. Hochmuth, and W. L. Laughlin. 2016. Leafy Greens in Hydroponics and Protected Culture for Florida. HS1279. Gainesville: University of Florida Institute of Food and Agricultural Sciences. Accessed March 30, 2020. https://edis.ifas.ufl.edu/hs1279

Reshmi, S. K., K. M. Aravinthan, and P. S. Devi. 2012. "Antioxidant analysis of betacyanin extracted from Basella alba fruit." International Journal of PharmTech. Research 4 (3): 900-913.

Rop, N. K., T. M. Mutui, and E. K. Kiprop. 2012. "Influence of nitrogen fertilizer on the growth, yield and quality of Indian spinach (Basella alba L.)." African Journal of Horticultural Science 6:111-117.

Singh, A., P. K. Dubey, R. Chaurasiya, N. Mathur, G. Kumar, S. Bharati, and P. C. Abhilash. 2018. "Indian spinach: An underutilized leafy vegetable for nutritional security in developing world." Energy, Ecology, and Environment 3 (3): 195-205.

Stephens, J. M. 2018. Spinach, Malabar-Basella rubra L. HS671. Gainesville: University of Florida Institute of Food and Agricultural Sciences. Accessed March 30, 2020. https://edis.ifas.ufl.edu/mv138 
USDA-ARS. 2012. "USDA Plant Hardiness Zone Map."

Agricultural Research Service, US Department of Agricul-

ture. https://planthardiness.ars.usda.gov/PHZMWeb/\#

USDA-ARS. 2019a. "National Nutrient Database for Standard Reference, Full Report (All Nutrients) 11587, Vine-spinach (Basella spp.), raw." https://fdc.nal.usda.gov/ fdc-app.html\#/?query=ndbNumber:11587

USDA-ARS. 2019b. "National Nutrient Database for Standard Reference, Full Report (All Nutrients) 11986, Malabar spinach, cooked." https://fdc.nal.usda.gov/fdc-app. html\#/?query=ndbNumber:11986

USDA-NRCS. 2020. "PLANTS profile for Basella alba (Ceylon spinach).” The PLANTS Database. National Plant Data Team, Greensboro, NC 27401-4901 USA. https:// plants.usda.gov/core/profile?symbol=BAAL2 
Table 1. Nutritive value of raw Malabar spinach (Basella spp.). Source: USDA-ARS, National Nutrient Database available at https:// fdc.nal.usda.gov/fdc-app.html\#/?query=ndbNumber:11587

\begin{tabular}{|c|c|c|}
\hline Name & Amount & Unit \\
\hline \multicolumn{3}{|c|}{ Variables } \\
\hline Water & 93.1 & $g$ \\
\hline Energy & 19 & kcal \\
\hline Energy & 79 & $\mathrm{~kJ}$ \\
\hline Protein & 1.8 & g \\
\hline Total lipid (fat) & 0.3 & $g$ \\
\hline Ash & 1.4 & $g$ \\
\hline Carbohydrate, by difference & 3.4 & g \\
\hline \multicolumn{3}{|l|}{ Minerals } \\
\hline Calcium, Ca & 109 & $\mathrm{mg}$ \\
\hline Copper, $\mathrm{Cu}$ & 0.107 & $\mathrm{mg}$ \\
\hline Iron, Fe & 1.2 & $\mathrm{mg}$ \\
\hline Magnesium, Mg & 65 & $\mathrm{mg}$ \\
\hline Manganese, $\mathrm{Mn}$ & 0.735 & $\mathrm{mg}$ \\
\hline Phosphorus, P & 52 & $\mathrm{mg}$ \\
\hline Potassium, $\mathrm{K}$ & 510 & $\mathrm{mg}$ \\
\hline Selenium, Se & 0.8 & $\mu \mathrm{g}$ \\
\hline Sodium, $\mathrm{Na}$ & 24 & $\mathrm{mg}$ \\
\hline Zinc, Zn & 0.43 & $\mathrm{mg}$ \\
\hline \multicolumn{3}{|l|}{ Vitamins } \\
\hline Vitamin A, IU & 8000 & IU \\
\hline Vitamin A, RAE & 400 & $\mu \mathrm{g}$ \\
\hline Vitamin B-6 & 0.24 & $\mathrm{mg}$ \\
\hline Vitamin B-12 & 0 & $\mu \mathrm{g}$ \\
\hline Vitamin C, total ascorbic acid & 102 & $\mathrm{mg}$ \\
\hline Vitamin D (D2 + D3) & 0 & $\mu \mathrm{g}$ \\
\hline Vitamin D (D2 + D3), International Units & 0 & IU \\
\hline Folate, total & 140 & $\mu \mathrm{g}$ \\
\hline Folic acid & 0 & $\mu \mathrm{g}$ \\
\hline Folate, food & 140 & $\mu \mathrm{g}$ \\
\hline Folate, DFE & 140 & $\mu \mathrm{g}$ \\
\hline Niacin & 0.5 & $\mathrm{mg}$ \\
\hline Pantothenic acid & 0.053 & $\mathrm{mg}$ \\
\hline Retinol & 0 & $\mu \mathrm{g}$ \\
\hline Riboflavin & 0.155 & $\mathrm{mg}$ \\
\hline Thiamin & 0.05 & $\mathrm{mg}$ \\
\hline \multicolumn{3}{|c|}{ Amino acids } \\
\hline Alanine & 0.075 & g \\
\hline Arginine & 0.07 & g \\
\hline Aspartic acid & 0.108 & g \\
\hline Cystine & 0.027 & g \\
\hline Glutamic acid & 0.283 & g \\
\hline Glycine & 0.067 & g \\
\hline Histidine & 0.039 & $\mathrm{~g}$ \\
\hline
\end{tabular}




\begin{tabular}{|c|c|c|}
\hline Isoleucine & 0.053 & $g$ \\
\hline Leucine & 0.101 & $g$ \\
\hline Lysine & 0.086 & $\mathrm{~g}$ \\
\hline Methionine & 0.019 & $g$ \\
\hline Phenylalanine & 0.085 & $g$ \\
\hline Proline & 0.07 & $g$ \\
\hline Serine & 0.057 & $g$ \\
\hline Tryptophan & 0.028 & $g$ \\
\hline Threonine & 0.055 & $g$ \\
\hline Tyrosine & 0.048 & $g$ \\
\hline Valine & 0.065 & $g$ \\
\hline \multicolumn{3}{|c|}{ Lipids } \\
\hline Cholesterol & 0 & $\mathrm{mg}$ \\
\hline Fatty acids, total trans & 0 & $g$ \\
\hline
\end{tabular}


Table 2. Nutritive value of cooked Malabar spinach. Source: USDA-ARS, National Nutrient Database available at https://fdc.nal. usda.gov/fdc-app.html\#/?query=ndbNumber:11986

\begin{tabular}{|c|c|c|}
\hline Name & Amount & Unit \\
\hline \multicolumn{3}{|c|}{ Variables } \\
\hline Water & 92.5 & g \\
\hline Energy & 23 & kcal \\
\hline Energy & 96 & $\mathrm{~kJ}$ \\
\hline Protein & 2.98 & g \\
\hline Total lipid (fat) & 0.78 & g \\
\hline Ash & 1.04 & g \\
\hline Carbohydrate, by difference & 2.71 & $g$ \\
\hline Fiber, total dietary & 2.1 & $g$ \\
\hline \multicolumn{3}{|l|}{ Minerals } \\
\hline Calcium, $\mathrm{Ca}$ & 124 & $\mathrm{mg}$ \\
\hline Copper, Cu & 0.111 & $\mathrm{mg}$ \\
\hline Iron, Fe & 1.48 & $\mathrm{mg}$ \\
\hline Magnesium, Mg & 48 & $\mathrm{mg}$ \\
\hline Manganese, Mn & 0.255 & $\mathrm{mg}$ \\
\hline Phosphorus, P & 36 & $\mathrm{mg}$ \\
\hline Potassium, $\mathrm{K}$ & 256 & $\mathrm{mg}$ \\
\hline Selenium, Se & 0.9 & $\mu \mathrm{g}$ \\
\hline Sodium, $\mathrm{Na}$ & 55 & $\mathrm{mg}$ \\
\hline Zinc, Zn & 0.3 & $\mathrm{mg}$ \\
\hline \multicolumn{3}{|l|}{ Vitamins } \\
\hline Vitamin A, IU & 1158 & IU \\
\hline Vitamin A, RAE & 58 & $\mu g$ \\
\hline Vitamin B-6 & 0.086 & $\mathrm{mg}$ \\
\hline Vitamin B-12 & 0 & $\mu \mathrm{g}$ \\
\hline Vitamin C, total ascorbic acid & 5.9 & $\mathrm{mg}$ \\
\hline Vitamin D (D2 + D3) & 0 & $\mu \mathrm{g}$ \\
\hline Vitamin D (D2 + D3), International Units & 0 & IU \\
\hline Folate, total & 114 & $\mu g$ \\
\hline Folic acid & 0 & $\mu \mathrm{g}$ \\
\hline Folate, food & 114 & $\mu g$ \\
\hline Folate, DFE & 114 & $\mu g$ \\
\hline Niacin & 0.787 & $\mathrm{mg}$ \\
\hline Pantothenic acid & 0.135 & $\mathrm{mg}$ \\
\hline Retinol & 0 & $\mu g$ \\
\hline Riboflavin & 0.129 & $\mathrm{mg}$ \\
\hline Thiamin & 0.106 & $\mathrm{mg}$ \\
\hline \multicolumn{3}{|l|}{ Lipids } \\
\hline Cholesterol & 0 & $\mathrm{mg}$ \\
\hline Fatty acids, total trans & 0 & g \\
\hline
\end{tabular}

